\title{
New Taste-blind Substances. Studies on the Sensory Divergence of Bitterness to the Taste-blindness of 2-Mercaptoimidazoline, 2-Mercaptobenzothiazole and Their Derivatives, with Special Reference to Their Molecular Structure
}

\author{
Katsushige Kouge, Tatsuya KoIzumi, Norio IsHibashi* \\ and Hideo OKAI**,† \\ Sanshin Chemical Industrial Co., Ltd., 531, Nagahama, Hirao-cho, \\ Kumage-gun, Yamaguchi 742-11, Japan \\ *Morinaga Milk Industry Co., Ltd., Nutritional Science Laboratory, \\ No. 4-22, 4-chome Meguro, Meguro-ku, Tokyo 153, Japan \\ ** Department of Fermentation Technology, Faculty of Engineering, \\ Hiroshima University, Shitami, Saijo-cho, \\ Higashihiroshima 724, Japan
}

Received February 2, 1987

\begin{abstract}
In order to investigate the relationship between taste-blindness and its chemical structure, sensory tests on thioureas, guanidines, imidazoles and thiazoles, which are widely used as vulcanizing agents for rubber, were carried out. It was found that new compounds, which had an intermediate characteristic between bitter and taste-blind substances, were present in benzimidazole and benzothiazole compounds. When it is considered that these compounds have structural similarities and only slight structural changes were present in them, these results provide an indication of the bitter exhibition mechanism on a taste receptor.
\end{abstract}

The occurrence of taste-blindness is widely known with respect to phenylthiourea. This phenomenon, which was first found by Fox, ${ }^{1)}$ has been defined by the fact that some specific substances are tasteless to a group of individuals, who seemed to be genetically defective in their bitter sensibility, while normal people could sense their bitterness. The tasteblind phenotype has prevailed by recessive heredity; e.g., Caucasians, Mongolians and Negroes respectively carry about 30,15 and $3 \%{ }^{2)}$ The substances that exert taste-blindness have a thiocarbamide group $(>\mathrm{NC}=\mathrm{S})$ as an essential part of their molecular structure. But some substances are exceptional, as exemplified by thiourea, which are always tasteless or cause only a slightly sour taste. Thiobarbituric acid is also tasteless, ${ }^{3)}$ while $N$-(4nitrophenyl)- $N^{\prime}$-(2-carboxyethyl)thiourea ex-

hibits strong sweetness instead of bitterness. ${ }^{4)}$

$$
\begin{gathered}
\stackrel{\stackrel{\mathrm{S}}{\mathrm{NH}_{2}-\mathrm{C}}-\mathrm{NH}_{2}}{\text { Thiourea }} \\
\end{gathered}
$$<smiles>NC(=O)CCCCCOCCOC=O</smiles>

Thiobarbituric acid<smiles></smiles>

$N$-(4-Nitrophenyl)- $N^{\prime}$-(2-carboxyethyl)thiourea

However, the relationship of taste exhibition and its chemical structure with taste-blindness has not been systematically studied, since only a limited number of these taste substances has been known to date. Two of the authors working in Sanshin Chemical Industrial Co., Ltd., which manufactures organic vulcanizing agents and produces organic sulfur com-

\footnotetext{
† To whom correspondence should be addressed.
} 
pounds together with guanidine or imidazole compounds noted that organic vulcanizing agents are suitable for a systematic study of taste-blindness, since there are numerous compounds in which a thiocarbamide group or its analogous groups are present in these molecules. About 30 species of water-soluble compounds among 100 products and synthetic intermediates from this manufacturer were examined for their taste-blind sensibility by the panels. In this paper, we describe the results of the taste-blind sensibility of these compounds and discuss its relationship with the chemical structure.

In a series of studies on bitter peptide, ${ }^{5 \sim 8)}$ we have been greatly interested in the bitter exhibition mechanism on the taste receptor, and have been always confronted with the problem of taste-blindness for clarifying this mechanism. Therefore, we considered that characterization of this phenomenon would give an important clue to understanding this mechanism.

\section{MATERIALS AND METHODS}

Preparation of the test compounds for taste-blindness. Phenylthiourea and caffeine, which were employed as the standard taste-blind or bitter compounds, were purchased from Tokyo Kasei Co., Ltd. Trimethylthiourea (1), tetramethylthiourea (2), sym-diethylthiourea (3), sym-nbutylthiourea (4), sym-diphenylthiourea (5), symdiphenylguanidine (6), sym-ditolylguanidine (7), 2-mercaptoimidazoline (8), 2-mercaptobenzimidazole (10), 2mercaptothiazoline (13), 2-mercaptobenzothiazole (15), 2mercapto-4-methylbenzothiazole (16), 5-chloro-2mercaptobenzothiazole (17), 2-benzothiazolone (19), and benzothiazole (20) were products manufactured by Sanshin Chemical Industrial Co., Ltd. Most of these are widely used as vulcanizing agents for rubber, and prior to sensory testing, they were recrystallized. The other compounds were chemically synthesized in the manner subsequently described.

2-Mercapto-4-methylbenzimidazole (11). To a mixture of 2-amino-6-methylaniline $(12.2 \mathrm{~g}, 0.1 \mathrm{~mol}), \mathrm{NaOH}(4 \mathrm{~g}$, $0.1 \mathrm{~mol})$ and water $(50 \mathrm{ml})$, carbone disulfide $(10 \mathrm{~g}$, $0.13 \mathrm{~mol}$ ) was added before refluxing for $2 \mathrm{hr}$. After being cooled to room temperature, the crystalline precipitate was collected by filtration and washed with water. This product was recrystallized from methanol. Yield 75\%; mp $295 \sim 300^{\circ}$ C. Anal. Found: C, 58.81; H, 4.53; N, $17.31 \%$.
Calcd. for $\mathrm{C}_{8} \mathrm{H}_{8} \mathrm{~N}_{2} \mathrm{~S}: \mathrm{C}, 58.54 ; \mathrm{H}, 4.87 ; \mathrm{N}, 17.06 \%$.

5-Chloro-2-mercaptobenzimidazole (12). This compound was synthesized from 2-amino-5-chloroaniline in a similar manner to that employed for 11. The crystalline precipitate was recrystallized from methanol. Yield $81 \%$; $300^{\circ} \mathrm{C}$ (decomposition; lit. $305^{\circ} \mathrm{C}$ ). ${ }^{9)}$ Anal. Found: C, $45.27 ; \mathrm{H}, 2.48 ; \mathrm{N}, 15.43 \%$. Calcd. for $\mathrm{C}_{7} \mathrm{H}_{5} \mathrm{~N}_{3} \mathrm{SCl}: \mathrm{C}$, $45.55 ; \mathrm{H}, 2.71 ; \mathrm{N}, 15.17 \%$.

2-Mercapto-6-nitrobenzothiazole (18). To a mixture of sulfuric acid $(15 \mathrm{ml})$ and nitric acid (fuming, $25 \mathrm{ml}$ ), 2mercaptobenzothiazole $(16.7 \mathrm{~g}, 0.1 \mathrm{~mol})$ was added at $0^{\circ} \mathrm{C}$ with stirring. The reaction mixture was allowed to stand for $2 \mathrm{hr}$ at the same temperature before being poured into ice-cooled water. The precipitated crude product was filtered and washed with water. The filter cake was dissolved in $10 \%$ ammonia water at $50{ }^{\circ} \mathrm{C}$, and the insoluble material was filtered off. The filtrate was adjusted to $\mathrm{pH} 2$ by adding $10 \% \mathrm{HCl}$. The product precipitated was filtered and washed with water, before being recrystallized from acetic acid. Yield $54 \%$; mp $250 \sim 255^{\circ} \mathrm{C} \quad$ (lit. $\left.255 \sim 257^{\circ} \mathrm{C}\right) .{ }^{10)}$ Anal. Found: C, 36.21; H, 2.87; N, $11.85 \%$. Calcd. for $\mathrm{C}_{7} \mathrm{H}_{4} \mathrm{O}_{2} \mathrm{~N}_{2} \mathrm{~S}_{2} \cdot \mathrm{H}_{2} \mathrm{O}: \mathrm{C}, 36.53 ; \mathrm{H}, 2.61$; $\mathrm{N}, 12.17 \%$.

Sodium benzothiazole-2-sulfinate (21). The solution of sodium 2-mercaptobenzothiazole $(50 \mathrm{~g}, 0.27 \mathrm{~mol})$ in water $(200 \mathrm{ml})$ was added to dropwise with $35 \% \mathrm{H}_{2} \mathrm{O}_{2}(55.3 \mathrm{~g})$ at a temperature of 0 to $5^{\circ} \mathrm{C}$. After being stirred for $1 \mathrm{hr}$ at 0 to $5^{\circ} \mathrm{C}$, the reaction mixture was evaporated in vacuo. The residue was crystallized from ethanol as hygroscopic crystals. Yield $57 \%$; IR (KBr): $1120 \mathrm{~cm}^{-1}, \quad 1330 \mathrm{~cm}^{-1}$ (sulfone).

Sodium benzothiazole-2-sulfonate (22). $100 \mathrm{ml}$ of an aqueous solution containing 2-mercaptobenzothiazole $(16.7 \mathrm{~g}, 0.1 \mathrm{~mol})$ and $\mathrm{NaOH}(4 \mathrm{~g}, 0.1 \mathrm{~mol})$ was added with $280 \mathrm{~g}$ of $12 \% \mathrm{NaOCl}$ at $80^{\circ} \mathrm{C}$, and was allowed to stand for $30 \mathrm{~min}$ at the same temperature. After being cooled to room temperature, the crystalline precipitate was filtered and recrystallized from ethanol. Yield $45 \% ; \mathrm{mp} 250^{\circ} \mathrm{C}$ (decomposition); Anal. Found: C, 33.21; H, 2.46; N, $5.21 \%$. Calcd. for $\mathrm{C}_{7} \mathrm{H}_{4} \mathrm{O}_{3} \mathrm{NS}_{2} \mathrm{Na} \cdot \mathrm{H}_{2} \mathrm{O}: \mathrm{C}, 32.95 ; \mathrm{H}, 2.35$; $\mathrm{N}, 5.49 \%$.

Benzothiazole-2-yl-propionic acid (23). Sodium 2-mercaptobenzothiazole $(26 \mathrm{~g}, 0.14 \mathrm{~mol})$ was dissolved in water $(100 \mathrm{ml})$. After standing at a temperature lower than $20^{\circ} \mathrm{C}$, $\beta$-propiolactone $(10 \mathrm{~g}, 0.14 \mathrm{~mol})$ was added dropwise for $30 \mathrm{~min}$. After being stirred for $3 \mathrm{hr}$ at the temperature below $20^{\circ} \mathrm{C}$, water $(100 \mathrm{ml})$ was added. The reaction mixture was acidified with $10 \% \mathrm{HCl}$ and filtered to obtain a white precipitate. The product was recrystallized from acetone. Yield $82 \%$; mp $145 \sim 148^{\circ} \mathrm{C}$. Anal. Found: C, $50.54 ; \mathrm{H}, 3.42 ; \mathrm{N}, 6.01 \%$. Calcd. for $\mathrm{C}_{10} \mathrm{H}_{9} \mathrm{O}_{2} \mathrm{NS}_{2}: \mathrm{C}$, $50.21 ; \mathrm{H}, 3.76$; N, $5.85 \%$. 
Sensory test. From among the members of our laboratory and numerous students in our department, tasteblind persons were selected by the sensory test of phenylthiourea. The test compounds, which had been dried over phosphorus pentaoxide at $60^{\circ} \mathrm{C}(2 \mathrm{mmHg})$ for $4 \mathrm{hr}$, were dissolved in deionized water. For each test compound, a series of solutions were prepared, which were sequentially diluted by one half. Most of the compounds, exhibiting a thione-thiole tautomeric isomer in solution, were insoluble in water, and were solubilized as the $\mathrm{Na}$ salt by adding the equivalent $\mathrm{NaOH}$. The taste of these solution was evaluated by 5 normal persons (group A) and by 5 taste-blind persons (group B). After rinsing the mouth of each panel member with deionized water, a series of solutions of each compounds were held in the mouth for about 10 seconds. The intensity and character of the taste were evaluated, and the threshold values were averaged across the panels for each compound.

\section{RESULTS AND DISCUSSION}

\section{Taste of thiourea and guanidine compounds}

The taste results of thiourea and guanidine compounds, which have a structure analogous to phenylthiourea, are shown in Table I. The thiourea derivatives $(\mathbf{1} \sim \mathbf{3})$, in which a methyl or ethyl group was introduced into the molecule, were tasteless. But when an $n$-butyl group was introduced, they exhibited a bitter taste. On the other hand, the diphenyl derivatives of thiourea (5) possessed stronger bitterness than did the alkyl derivatives, and exhibited apparent taste-blind sensibilily. With the compound 6 or 7 , in which the thione sulfur atom of thiourea was replaced by an imino group, the taste was simple bitterness. The apparent taste-blindness observed with $\mathbf{5}$ was considered to be equivalent to that observed with phenylthiourea.

\section{Taste of imidazole compounds}

It is well known that the 2-mercaptoimidazole and 2-mercaptothiazole compounds can be present in the tautomeric structure shown in the following equation:<smiles>[X]c1cc(SCCSc2[nH]cc(C)c2N)[X]c1S</smiles>

Imidazoles $(\mathrm{X}=\mathrm{NH})$ Thiazoles $(\mathrm{X}=\mathrm{S})$

Thione form Thiole form

TABle I. TASTE OF Thiourea AND GuANIDINE CoMpounds

\begin{tabular}{|c|c|c|c|}
\hline \multirow[b]{2}{*}{ No. } & \multirow[b]{2}{*}{ Compound } & \multicolumn{2}{|c|}{ Taste $^{a}$} \\
\hline & & $\mathrm{A} \frac{\mathrm{T} . \mathrm{V} .}{(\mathrm{mM})}$ & $\mathrm{B} \frac{\text { T.V. }}{(\mathrm{mM})}$ \\
\hline 1 & 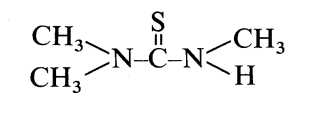 & $\begin{array}{c}\text { No taste } \\
-\end{array}$ & $\begin{array}{c}\text { No taste } \\
-\end{array}$ \\
\hline 2 & $\begin{array}{l}\mathrm{CH}_{3} \\
\mathrm{CH}_{3}\end{array} \mathrm{~N}-\stackrel{\mathrm{I}}{\mathrm{C}}-\mathrm{N}=\underset{\mathrm{CH}_{3}}{\mathrm{CH}_{3}}$ & No taste & No taste \\
\hline 3 & 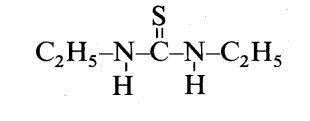 & $\begin{array}{c}\text { No taste } \\
-\end{array}$ & $\begin{array}{c}\text { No taste } \\
-\end{array}$ \\
\hline 4 & 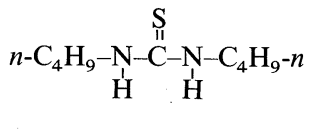 & $\begin{array}{r}\text { Bitter } \\
0.42\end{array}$ & $\begin{array}{r}\text { Bitter } \\
0.42\end{array}$ \\
\hline 5 & $\begin{array}{rr}1 & 1 \\
H & H\end{array}$ & $\begin{array}{r}\text { Bitter } \\
0.10\end{array}$ & $\begin{array}{c}\text { No taste } \\
-\end{array}$ \\
\hline 6 & $\begin{array}{ll}1 \\
\mathrm{H}\end{array}$ & $\begin{array}{r}\text { Bitter } \\
0.30\end{array}$ & $\begin{array}{r}\text { Bitter } \\
0.30\end{array}$ \\
\hline 7 & 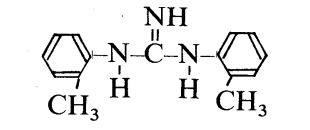 & $\begin{array}{r}\text { Bitter } \\
0.03\end{array}$ & $\begin{array}{r}\text { Bitter } \\
0.03\end{array}$ \\
\hline & Caffeine & $\begin{array}{c}\text { Bitter } \\
1.0\end{array}$ & $\begin{array}{c}\text { Bitter } \\
1.0\end{array}$ \\
\hline & Phenylthiourea & $\begin{array}{r}\text { Bitter } \\
0.03\end{array}$ & No taste \\
\hline
\end{tabular}

a A, normal persons; B, taste-blind persons; T.V., threshold value.

The thione form is generally the dominate tautomer and it is slightly soluble in water. In the sensory test for $\mathbf{8}$, we prepared its sodium salt by adding equivalent $\mathrm{NaOH}$ to provide sufficient solubility for the sensory test. Consequently, both 8 and 9 exhibited tasteblind sensibility, as shown in Table II. This fact enabled us to carry out sensory tests on other imidazole compounds and thiazole compounds, which are subsequently described in the next paragraph. 2-Mercaptobenzimidazole (10) also exhibited the taste-blind sensibility. 
TABle II. TASTE of Imidazole Compounds

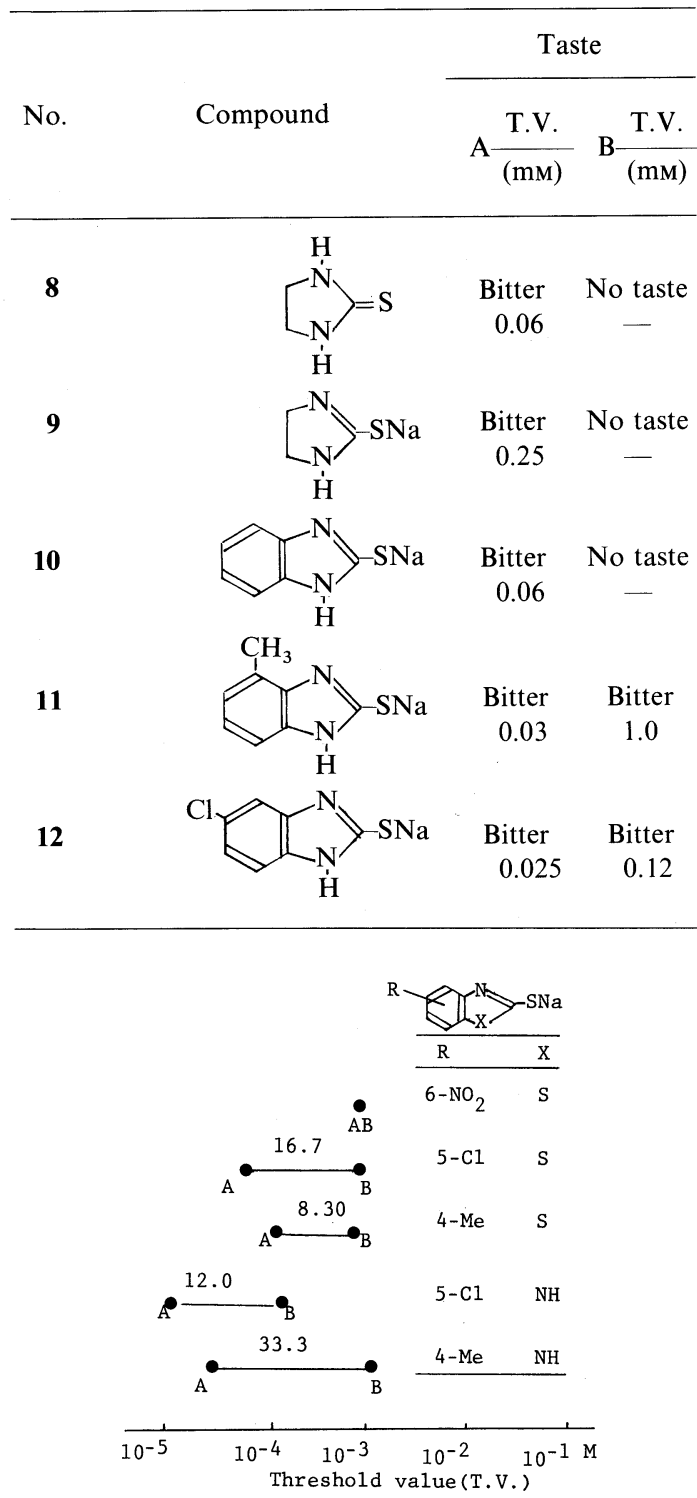

FIG. 1. Bitter Intensity between a Normal Person and Taste-Blind Person in Benzimidazole and Benzothiazole Compounds.

A, threshold value for a normal person; $B$, threshold value for a taste-blind person. The values on the figure are $\mathrm{B} / \mathrm{A}$.

With the compound $\mathbf{1 1}$ or $\mathbf{1 2}$, in which a methyl group or chlorine atom was introduced into the benzene ring of $\mathbf{1 0}$, a bitter taste was declared by both the normal and taste-blind panels. However, the intensity of bitterness for the taste-blind panel was between one tenth
Table III. Taste of Thiazole Compounds

No. \begin{tabular}{c} 
Taste \\
\cline { 3 - 3 } 13
\end{tabular}

19

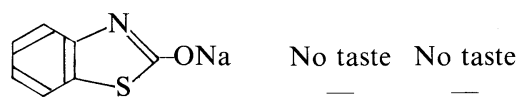

20

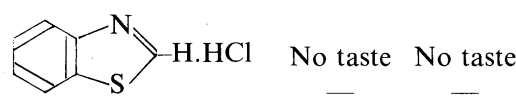

21

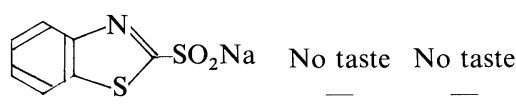

22

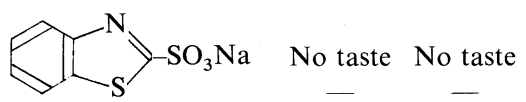

23

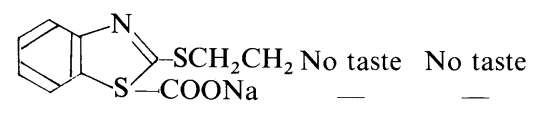

and one fifteenth that for the normal panels. This characteristic was not observed in phenylthiourea. Therefore, these substances were concluded to be the intermediate between ordinarily bitter and taste-blind substances. 
Taste of thiazole compounds

In 2-mercaptothiazoline (13), which was reported as taste-blind substance by Hopkins, ${ }^{3)}$ we also observed taste-blind sensibility, as shown in Table III. The taste pattern for thiazole compounds $(15,16$ and 17) was the same as that of the imidazole compounds. Although 2-mercaptobenzothiazole (15) exhibited taste-blind sensibility similar to that observed in phenylthiourea, the compound 16 or 17 , in which a methyl group or chlorine atom was introduced in the benzene ring of 15, showed an intermediate character between an ordinarily bitter and taste-blind substance. On the other hand, the compound 18, in which a nitro group was introduced into the benzene ring, returned the original bitter taste. We then tested several compounds in which the thione sulfur atom in $\mathbf{1 5}$ was replaced by other groups. These were tasteless instead of bitter or sweet.

\section{CONCLUSION}

During this study, we found several new taste-blind substances from vulcanizing agents. In addition, we recognized that these substances had an intermediate character between bitter and taste-blind substances. These substances are illustrated in Fig. 1, which shows that a slight structural change in benzimidazole and benzothiazole compounds varied their bitter taste profile from simple bitterness to taste blindness or to an intermediate level. These facts lead us to the conclusion that the structure of the bitter taste receptor in the gustation cells of normal and taste-blind subjects is essentially identical and only a slight difference exists. This is compatible with the observation that the trait of taste-blind sensibility is caused by recessive racial heredity.

\section{REFERENCES}

1) A. L. Fox, Proc. Natl. Acad. Sci. U.S.A., 18, 115 (1932).

2) Y. Ariyoshi, Yuki Gosei Kagaku Kyokai Shi, 35, 369 (1977).

3) C. Y. Hopkins, Can. J. Res., 20B, 268 (1942).

4) S. Pertersen and E. Müller, Chem. Ber., 81, 31 (1948).

5) H. Okai, "Peptide Chemistry 1976," ed. by T. Nakajima, Protein Research Foundation, Osaka, 1977, p. 139.

6) I. Shinoda and H. Okai, J. Agric. Food Chem., 33, 792 (1985).

7) K. Otagiri, Y. Nosho, I. Shinoda, H. Fukui and H. Okai, Agric. Biol. Chem., 49, 1019 (1985).

8) Y. Nosho, K. Otagiri, I. Shinoda and H. Okai, Agric. Biol. Chem., 49, 1829 (1985).

9) B. H. Chase and W. T. Weller, J. Pharm. Pharmacol., 16, 163 (1964).

10) J. Teppma and L. B. Sebrella, J. Am. Chem. Soc., 49, 1779 (1927). 